\title{
КЛАСИФІКАЦІЯ КАТУВАННЯ, ЩО СКОЮЄТЬСЯ ПРАЦІВНИКАМИ ПРАВООХОРОННИХ ОРГАНІВ, НА ПІДСТАВІ СПОСОБУ ЙОГО ВЧИНЕННЯ
}

\section{Іенатов О М}

кандидат юридичних наук, старший науковий співробітник Інститут економіки та права (філія) ОУП ВПО

“Академія праці та соціальних відносин”, м. Севастополь

\section{I. Вступ}

Катування сьогодні, на жаль, є типовою, характерною рисою діяльності працівників правоохоронних органів не лише нашої країни, але й багатьох інших країн, особливо на пострадянському просторі. Це підтверджує не лише наявність відповідних статистичних даних, а й великий суспільний резонанс навколо подібних випадків, що призводить до ініціації у суспільстві питання про необхідність реформування системи правоохоронних органів.

Розробка ефективних заходів протидії цьому негативному явищу та потреба вдосконалення практики втілення їх у життя зумовлює необхідність розробки відповідної класифікації, а відповідно, подальше глибоке дослідження окремих видів катування.

Дійсна сутність явищ та їх властивостей може виявитися лише у зв'язку, у порівнянні з іншими, що дає можливість глибше досліджувати явище в цілому, побачити його розвиток і вплив на інші явища [1, с. 14-15]. Під класифікацією злочинів розуміють поділ їх на групи залежно від того чи іншого критерію [2, с. 75], а здійснюватися вона повинна, виходячи з умов формальної логіки. Цю дію необхідно проводити з урахуванням таких методів теорії пізнання, як системний підхід до вивчення окремих об'єктів і явищ, висування гіпотез, моделювання [3, с. 97].

Проблема класифікації злочинів розглядалася багатьма вченими, зокрема, такими як А.І. Алексєєв, А.П. Закалюк, О.М. Джужа, А.І. Долгова, І.І. Карпець, Л.В. Кондратюк, Л.М. Кривоченко та ін. Однак поява все нових видів проявів незаконного насильства в діяльності працівників правоохоронних органів зумовлює необхідність подальшого наукового пошуку в цьому напрямі.

\section{II. Постановка завдання}

Метою статті $є$ розроблення класифікації катувань, що вчиняються працівниками правоохоронних органів. Новизна дослідження полягає в розробці цієї класифікації за критерієм виду насильства та механізму його реалізації (способу вчинення) при здійсненні катування цією категорією правопорушників.
Залежно від мети і завдань застосовуються різні підходи щодо групування чи класифрікації злочинів, які перебувають в основі структурування злочинності. Класифрікація має здійснюватись на підставі кримінологічно значущих ознак з урахуванням закономірностей розвитку та функціонування об'єктів дослідження. Одним із основних критеріїв класифікації катувань, на наш погляд, є вид насильства та механізм його реалізації (спосіб вчинення) при здійсненні катування.

\section{III. Результати}

Загалом, під насильством, як способом вчинення злочину (іншого правопорушення), слід розуміти умисний, протиправний енергетичний вплив на органи і тканини організму людини, їх фрізіологічні фрункиії, шляхом використання матеріальних фракторів зовнішнього середовища (механічних, фрізичних, хімічних і біологічних) та/або вплив на їі психіку шляхом інформаційного впливу, що вчиняється шляхом дії або через бездіяльність всупереч або поза їі (людини) волі, здатний заподіяти смерть, фрізичну та/або психічну травму, а також обмежити свободу волевиявлення або дій людини [4, с. 146].

У зв'язку з тим, що людина $є$ єдністю двох взаємодіючих підструктур - біологічної і надбіологічної (психіки), фізичне насильство над людиною може мати як наслідки заподіяння психічних травм, так само, як наслідками впливу на психіку можуть бути порушення фрізіологічних функцій організму і навіть смерть людини. Наприклад, такі фрізичні насильницькі дії, як введення в кору головного мозку відповідних хімічних речовин, електронна стимуляція мозку можуть вкрай згубно вплинути на психіку людини. Спричинення психічної травми можливе також через фізичний вплив безпосередньо на тіло людини (катування тощо).

Як фрізичний, так і психічний насильницький вплив можуть здійснюватися людиною:

а) безпосередньо - шляхом особистого контакту (використовуючи можливості свого організму - фрізичні або психічні). Використовуючи свої фрізичні можливості, людина 
може використовувати м'язову силу свого тіла (наприклад, нанесення ударів, здавлення шиї тощо) або різні механізми, пристосування, інші засоби вчинення злочину (наприклад, удар ножем чи постріл зі зброї тощо) для посилення м'язової сили тіла;

б) опосередковано - використовуючи поведінку іншої людини, яка не є суб'єктом злочину, інших живих істот;

в) шляхом опосередкованого виконання - за допомогою усвідомленого і цілеспрямованого використання різних процесів і явищ зовнішнього світу.

Що стосується конкретних можливих шляхів реалізації катування або іншого акту незаконного насильства, тобто методів, послідовності рухів та прийомів чи сукупності засобів, що використовуються для його вчинення, то найбільш типовими формами реалізації насильницького способу вчинення катування $€$ такі.

Найбільш поширеним способом вчинення катування $є$ тілесні ушкодження. Побоїне становлять особливого виду ушкоджень та характеризуються заподіянням багаторазових ударів. Мучення (заподіяння мук)вчинення тривалих за часом і безперервних у своїй змістовній сукупності умисних діянь, що позбавляють потерпілого необхідних природних умов його життєдіяльності (їжі, пиття, тепла тощо) або залишають його в шкідливих для здоров'я умовах тощо, внаслідок чого заподіюють йому фізичний біль. Мордування - багаторазове та/або тривале спричинення болю: щипання, шмагання, нанесення численних, але невеликих ушкоджень тупими чи гостроколючими предметами, діяння термічних факторів та інші аналогічні дії. Слід зазначити, що, на відміну від побоїв, при яких винною особою використовуються механічні фрактори зовнішнього середовища (дія кінетичної енергії певного предмета), мучення та мордування може здійснюватися з використанням дії фрізичних факторів зовнішнього середовища (дія високих чи низьких температур, підвищеного i зниженого барометричного тиску, ушкодження електричним струмом, вплив різними видами променистої енергії, дії тощо). Тортури - насильницькі дії, що мають характер побоїв, мордування або мучення, спосіб вчинення яких характеризується більшою тривалістю у часі та/або витонченим поєднанням зазначених форм фрізичного насильства між собою та/або з різними формами психічного впливу на потерпілого. Знущання - цинічне приниження гідності та ганьблення честі потерпілого. Глумління являє собою найбільш гостру (тяжку) фрорму знущання, що характеризується виключним цинізмом вчинюваних дій.

Також типовими формами реалізації акту незаконного насильства є різнорідні погрози (вбивство, застосування фізичної сили, позбавлення волі, притягнення до кримінальної відповідальності, поширення різних відомостей, пошкодження або знищення майна, підпал, позбавлення матеріального забезпечення тощо); примус; образа, залякування; наклеп тощо [4].

Що стосується безпосередньо особливостей катування, що вчиняється працівниками правоохоронних органів, то найбільш типовими способами його вчинення $є$ такі.

1. Застосування фізичного насильства (як правило, фрізичний вплив на жертву характеризується довготривалістю у часі, включаючи нічний час):

- побиття:

а) нанесення ударів по різних частинах тіла (найчастіше по спині, шиї, нирках, вухах, п'ятках, у пах, під ребро, по голові) руками (часто використовуються боксерські рукавиці), ногами, гумовим кийком, гумовим шлангом, ременем, палицею, ніжкою стільця, шваброю та іншими предметами (часто використовуються книги, шматки фанери, пластикові пляшки з водою, мішечки з піском тощо, а також замотують голову ковдрою та через неї наносять удари);

б) наступання ногами на руки, ноги, статеві органи, шию;

в) викручування, виламування пальців, суглобів; затискання пальців рук у тисках, пристрої для прошивання кримінальних справ тощо;

г) встромляння (затискання) між пальців рук олівців, ручок тощо та здавлювання долоні (якщо залишаються рани, вони заживають дуже тривалий час через постійне побутове травмування цих ділянок тіла);

д) стрибання на різні частини тіла зі стільця, столу;

е) "парашут”, “горобець” - підняття за руки та за ноги та підкидання з подальшим падінням ниць на підлогу (сліди, як правило, не залишаються або ж схожі на самостійне падіння зі сходів, нар тощо);

ж) “дзвін”, “дзвонар” - сковування за спиною наручниками рук та надягання на голову металевого відра, по якому наносяться удари гумовим кийком, палкою, ніжкою стільця, гантеллю тощо;

- примушування до виконання виснажливих фрізичних вправ (віджиматися багато разів під рахунок від підлоги, присідати, лягати-вставати тощо) або до виконання робіт (мити протягом доби підлогу тощо);

- тримання у незручних позах (вивих суглобів, а також переривання кровопостачання у кінцівки викликають нестерпний біль та призводить до серйозних тілесних ушкоджень):

а) примушування стояти чи сидіти у певній позі (наприклад, “орел" - тривале стоян- 
ня на зігнутих у колінах ногах на дуже маленькому за площею стільці; зігнувши ноги у колінах стояти з протягнутими у перед руками тривалий час; стояти біля стіни, тримаючи у розведених по сторонах руках гантелі; стояти чи сидіти зі скованими у наручники руками та прив'язаною до них або до шиї гирею; використання різноманітних шпагатів-розтяжок тощо);

б) “ластівка" - руки жертви сковують наручниками за спиною та приковують до них ноги;

в) "папуга" - руки жертви сковують наручниками за спиною та приковують до них ноги (або сковують наручниками руки та ноги із затиснутою між ними головою), у такій позі тіло вішають на металевий лом, трубу, палицею та наносять удари, прокручуючи тіло;

г) "конверт", “лист" - голову жертви поміщають між ніг (між колін) та сковують наручниками (зв'язують) руки з ногами;

д) “диба" - підвішування у незручних позах - руки жертви сковують наручниками за спиною та підвішують за них до решітки на вікні тощо, щоб ноги не торкалися підлоги; підвішують до батареї опалення та збивають жертву з ніг; руки та ноги жертви сковують наручниками за спиною та підвішують на просунутий металевий лом, трубу, палку, яка лежить між вдома стільцями, столами;

- катування струмом - "детектор брехні” - застосовуються різноманітні електроприлади, найчастіше - польовий телефон або електрошокер (проводи, контакти приєднуються, як правило, до пальців рук, ніг, вух, сосків, статевих органів, анального отвору);

- катування вогнем (рідше застосовують кип'яток): припалювання різних частин тіла (пальців, вух, статевих органів, сосків, п'ят, нирок тощо) полум'ям запальнички, сигаретою; примушування збирати гарячі недопалки цигарок з підлоги зубами тощо;

- асфріксія (будь-яким шляхом перекривається доступ повітря до дихальних шляхів та припиняється, як правило, за проханням жертви чи при появі конвульсій; практично не залишає жодних слідів; часто поєднуються 3 побиттям 3 метою збільшення частоти дихання жертви):

а) "слоник" - надягання на голову протигазу та закриття отвору, через який надходить повітря;

б) "цивільна оборона" - надягання на голову протигазу та видихання до отвору, через який надходить повітря, диму від цигарок чи вприскування дихлофосу тощо;

в) "магазин” - надягання на голову поліетиленового пакета та перекриття повітря шляхом його скручування (замотування скотчем) на шиї; д) “шапка Мономаха" - надягання на голову та обличчя зимової шапки (пакета), у яку був налитий нашатирний спирт;

е) утоплення у відрі з водою, відходами, туалеті тощо;

- позбавлення ліків (наприклад, відмова особі, залежній від інсуліну, у наданні медичної допомоги) або застосування різних хімічних речовин (найчастіше, насильницьке введення через гумовий шланг у шлунок розчину солі; заливання до горла нашатирного спирту; заливання до горла жертви спирту, горілки при наявній інформації про хімічне кодування від алкоголізму тощо);

- сексуальне насильство - зґвалтування жертв незалежно від статі; введення у статеві органи різних предметів (сірників чоловікам, гумового кийка жінкам, гумового кийка, ніжки стільця чоловікам тощо); відбивання книжкою, шматком франери, гумовим кийком грудей жінкам; стискання сосків пасатижами, плоскогубцями; примушування жертв до вчинення один з одним статевого акту тощо.

2. Застосування психічного насильства (як правило, психічний вплив на жертву характеризується агресивними вербальними формами поведінки у сполученні з застосуванням інших принижуючих чи болісних способів впливу з метою повної дезорієнтації жертви, доведення її до стану шоку і, як наслідок, втрати контролю над дійсністю та підпорядкування ії̈ собі):

- пряма психічна агресія (різка зміна ввічливого ставлення до жертви на вкрай негативне):

а) принизливе ставлення до людини, життя якої повністю залежить від правоохоронців; психічний тиск та дезорієнтація особи відносно вчиненого нею (інкримінованого їй) діяння та можливого покарання і її подальшого становища (залякування смертною карою або різними нелюдськими видами покарання, тривалим терміном ув'язнення, умовами відбування покарання тощо);

б) ображання вкрай цинічними словами (нерідко з використанням найбільш вразливих сторін життя особи - каліцтва, національності, віросповідання, кольору шкіри, соціального статусу тощо), нецензурною лайкою;

в) повне ототожнення жертви (у своєму ставленні до неї та поведінці з нею) з твариною тощо;

- погрози:

а) погроза застосуванням фрізичного насильства (відбувається у вербальній формі та, як правило, супроводжується, демонстрацією засобів та знарядь катування тощо);

б) погроза застосуванням сексуального насильства:

- погроза вчиненням за вказівкою працівника ОВС $з$ жертвою насильницького 
статевого акту співкамерником, який страждає на СНІД чи ВІЛ-інфекцію;

- демонстрація засобів та знарядь вчинення сексуального насильства (надягання презерватива на гумовий кийок; ніжку перевернутого стільця тощо);

- погроза (намагання) вчинення над жертвою сексуального насильства з фіксацією цього акту на відео- або фотоапаратуру з подальшим розповсюдженням серед знайомих жертви (цей захід часто застосовується до осіб, які мають стосунок до кримінального світу та не можуть допустити наявності такої компрометуючої інфрормації);

в) погроза позбавлення життя:

- демонстрація зброї (при допиті жертви демонстративно розбираєтьсязбирається табельна зброя, натискається, ніби випадково, спусковий гачок; робиться несподіваний постріл в обличчя жертви з незарядженої зброї, з подальшим заряджанням зброї та погрозою зробити постріл; погроза-пропозиція залишити приміщення, вистрибнути у вікно $з$ подальшим позбавленням життя при спробі втечі тощо);

- вивезення жертви до безлюдних місць (звалище, ліс, незавершене будівництво та ін.), примушування копати собі могилу тощо;

- вчинення обманних дій щодо позбавлення життя (наприклад, жертву прив'язують за руки та ноги до крісла, стільця з підлокітниками, голову закидають назад та фріксують або надягають на неї мішок чи зав'язують очі, жертві повідомляють, що зараз їй будуть перерізати вени та демонструють лезо бритви, ножа, а потім тупою стороною леза з силою проводять по зап'ястках та через дві-три секунди починають повільно лити на них підготовлену теплу воду);

г) погроза вчинення протиправних дій відносно членів родини або близьких осіб (часто застосовується при тривалій ізоляції жертви від зовнішнього світу, яка позбавлена можливості контролювати стан справ у родині, близькому оточенні, або до тією чи іншою мірою вразливих осіб - матері-одинаки, особи, які мають батьків похилого віку, тощо);

- застосування (демонстрація застосування) насильства до інших осіб:

а) на очах особи катують іншу людину (часто для цього допитують разом “співучасників" або родичів чи близьких жертви);

б) особа чує процес або бачить результат катування іншої людини;

- систематичне монотонне повторення однієї моделі поведінки (як правило, систематичне відтворення моделі поведін- ки поєднується 3 повним ігноруванням жертви):

а) систематичне повторення лише одного й того самого слова (часто образливого, наприклад, “лох”, “попадалець”, “свиня” тощо) або жесту, руху тіла тощо;

б) бездіяльність або повне ігнорування (психічний вплив також може полягати не лише у дії, а й у бездіяльності: неповідомлення необхідної потерпілому інформації, перш за все, відносно його місця знаходження, процесуального статусу, підстав його затримання; стану справ у родині, близькому оточенні тощо або ігноруванні прохань жертви від надання можливості відправити вітальні потреби, надання медичної допомоги до надання захисника тощо.

3. Змішана форма насильства (полягає у комбінованому впливі на жертву, що характеризується як простим (побиття та залякування, насильницьке заливання у горло спирту та примушування танцювати тощо), так і витонченим поєднанням фрізичного й психічного впливу):

а) позбавлення нормальних (природних) умов існування життєдіяльності (їжі, пиття, тепла; можливості відвідати туалет тощо та обіцянка їх надання в обмін на інформацію або вчинення певних дій);

б) ставлення (залишення) у шкідливі для життя (здоров'я) умови (тримання в приміщенні без світла, вентіляції, з ненормальним температурним режимом, в антисанітарійних умовах;

в) насильницький вплив на організм людини з метою викликати болісні відчуття та позбавлення можливості їх уникнути: різноманітні “дієти" - жертву пригощають (або 3 продуктів харчування надають лише одне) мінеральною водою, кавуном, пивом тощо, а потім позбавляють можливості відвідати туалет; жертву пригощають (або з продуктів харчування надають лише одне) солоним, кислим тощо, а потім позбавляють можливості задовольнити спрагу тощо.

Окремо слід відзначити такий спосіб вчинення працівниками ОВС актів незаконного насильства, як пряме залучення або опосередковане використання поведінки інших осіб. Це, як правило, погроза використання або пряме використання “своїх" ув'язнених (або цілих "прес-хат") з метою застосування фрізичного насильства до жертви чи психічного тиску на неї.

\section{IV. Висновки}

Отже, надана класифікація, на наш погляд, дала змогу виокремити основні види катувань, що вчиняються працівниками правоохоронних органів на підставі особливостей способу вчинення, що дає можливість подальшого їх глибокого дослідження 3 метою розробки та диференціації заходів протидії. 


\section{Література}

1. Кривоченко Л.Н. Классификация преступлений / Л.Н. Кривоченко. - Х. : Вища шк., 1983. - 129 с.

2. Кримінальне право України. Загальна частина / [під ред. М.І. Бажанова, В.В. Сташиса, В.Я. Тація]. - К ; Х. : Юринком IHтер-Право, 2002. - 414 с.
3. Даньшин И.Н. Введение в криминологическую науку / И.Н. Даньшин. - Х. : ПраBo, 1998. -144 c.

4. Ігнатов О.М. Насильство як спосіб вчинення злочину: поняття та сутність [Електронний ресурс] / О.М. Ігнатов // Форум права. - 2010. - № 3. - С. 144-151. Режим доступу: http://www.nbuv.gov.ua/ e-journals/FP/2010-3/10iomptc.pdf.

Ігнатов О.М. Класифікація катування, що скоюється працівниками правоохоронних органів, на підставі способу його вчинення

Анотація. Статтю присвячено проблемі класифрікації катування, що скоюється працівниками правоохоронних органів. Розроблено їх класифрікацію на підставі способу вчинення.

Ключові слова: катування, насильство, правоохоронні органи, класифрікація.

Игнатов А.Н. Классификация истязания, которое совершается работниками правоохранительных органов, на основании способа его совершения

Аннотация. Статья посвящена проблеме классификации истязания, которое совершается работниками правоохранительных органов. Разработана их классификация на основании способа совершения.

Ключевые слова: истязание, насилие, правоохранительные органы, классификация.

Ignatov A. Classification of tortures, law enforcement authorities accomplished workers, on the basis of method of feasance

Annotation. The article is devoted the problem of classification of tortures, law enforcement authorities accomplished workers. Their classification is developed in accordance with the method of feasance.

Key words: tortures, violence, law enforcement authorities, classification. 